\title{
Hardpan Effect on Sugarcane Transpiration, Growth and Yield
}

\author{
Samuel M. Contreras* and Kiyoshi Ozawa**, ${ }^{*}$ \\ (* Bureau of Soils and Water Management, Philippines, Diliman Quezon City, Philippines \\ ** Japan International Research Center for Agricultural Sciences Okinawa Subtropical Station, \\ Ishigaki Island, Okinawa, 907-0002 Japan
}

\begin{abstract}
In recent years, mechanical cultivation has been introduced widely in developing countries. Tillage hardpan is known to affect plant roots' water absorption as it limits root penetration and soil water movement within the soil profile. However hardpan studies from crop science aspects are few. Therefore the effect of hardpan on transpiration, growth and yield of sugarcane was studied in the Japan International Research Center for Agricultural Sciences (JIRCAS) Okinawa Subtropical Station in Ishigaki Island, to find means of mitigating its impact on agriculture.

An open field was divided into plots of disrupted and the undisrupted hardpan. Sugarcane cuttings were planted in the field in December 2000. Transpiration was measured using sap flow gauges in September 2001 when the crop canopy fully developed. Transpiration in the disrupted hardpan plot was almost equal to its meteorological potential. However, that in the undisrupted hardpan plot was half of the potential. Transpiration in the undisrupted hardpan plot did not increase even after precipitation increased, though roots in the undisrupted hardpan plot developed greatly in the shallow soil where the water filled rapidly. This indicates that limited transpiration in the undisrupted hardpan plot was due not only to soil water deficit. An irreversible decrease in stomatal conductance led to the result, because the ratio of transpiration per leaf area was quite low in the undisrupted hardpan plot. It resulted in the crop water content in the undisrupted hardpan plot increasing. A stomatal decrease in conductance generally decreases growth and yield due to the lessened photosynthesis. Yield increased in the disrupted hardpan plot. This shows that available means for fields in which hardpan has developed are not only hardpan disruption but also cultural practices to prevent stomatal conductance from decreasing. The yield in both plots increased as stem numbers increased. This suggests that drainage and aeration during the rainy season when available stems emerge also might increase yield in the disrupted hardpan plot.
\end{abstract}

Key words: Growth, Hardpan, Sugarcane, Transpiration, Yield.

\section{Introduction}

Hardpan, a dense layer of soil, is divided into two types; one is a natural occurrence and the other is from tillage operation by plow, rotary or wheel traffic. In this paper, we treat the latter, which typically lies between $15 \mathrm{~cm}$ and $40 \mathrm{~cm}$ below the soil surface. Tillage hardpan is accompanied by a reduc-

\footnotetext{
${ }^{\dagger}$ Corresponding Author

Presented at the International Symposium on Food Production and Environmental Conservation in the Face of Global Environmental Deterioration (FPEC) on September 8, 2004.

Received on August 23, 2004.

Accepted on December 8, 2004.
}

tion in porosity of a soil layer a few $\mathrm{cm}$ thick as soil particles are forced together. These changes in porosity can significantly restrict root growth, water and air transaction and yield (Kramer and Boyer, 1995; Oussible et al., 1992). Hard soil restriction of root growth is larger in clay soil (Gill and Miller, 1956) due to sub-soil air oxygen shortage (Grimes et al., 1975). These physical effects of hardpan are well known; however, practical hardpan effects on the crop responses have been little analyzed.

This paper attempts to analyze the response of sugarcane to the presence of hardpan in terms of transpiration, crop growth and yield. The analysis was done by comparing crop performance in plots with disrupted and undisrupted hardpan. 


\section{Materials and Methods}

\subsection{Experimental site description}

The study was conducted at JIRCAS Okinawa Subtropical Station, Ishigaki Island, Okinawa, Japan. Cutting stems with two nodes of sugarcane, cultivar Ni 8 , were planted with $35 \mathrm{~cm}$ distances in rows $140 \mathrm{~cm}$ apart on December 24, 2000. Ishigaki Island has a sub-tropical climate. It received an annual precipitation of $2,536 \mathrm{~mm}$ and a annual average air temperature of $24.5^{\circ} \mathrm{C}$, with a average daily maximum temperature of $30.0^{\circ} \mathrm{C}$ in August and a average daily minimum of $19.6^{\circ} \mathrm{C}$ in January during the year of the cropping.

The study area was a $12 \times 23 \mathrm{~m}$ rainfed open field, which consisted of 8 rows of north-south direction. The field was divided into 4 plots such that two opposite plots consisted of undisrupted and disrupted hardpan. The hardpan layer, identified at $30 \mathrm{~cm}$ to $40 \mathrm{~cm}$ below the surface, consists of sandy clay loam soil with a massive structure. Figure 1 shows penetration resistance distribution of a soil profile in the undisrupted hardpan plot. In the disrupted hardpan plot, hardpan was broken up using a machine folk, inserting it into soil vertically, and then moving it up with soil. The hardpan disruption did not affect the penetration resistance distribution; however, it made cracks in the soil below the hardpan.

\subsection{Meteorological measurement and analysis}

Daily precipitation, air temperature, relative humidity, sunshine hours and wind velocity in September 2001 were obtained from Ishigaki Weather Station. Daily estimated transpiration was calculated

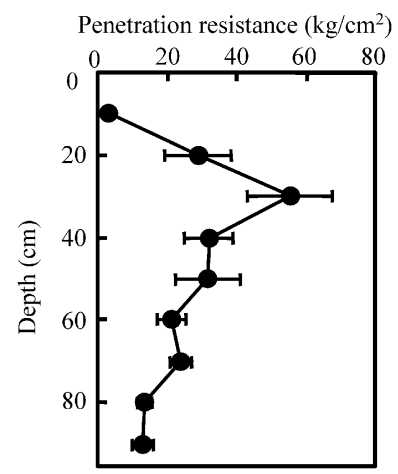

Fig. 1. Distribution of penetration resistance in undisrupted hardpan profile. Dots show means. Bars show standard deviations. through the FAO Penman-Monteith method by applying a crop coefficient of 1.25 (Allen et al., 1998).

\subsection{Transpiration measurement}

Transpiration measurements were conducted in September 2001 using sap flow gauges. These gauges measure sap flow through the heat energy balance method outlined by Sakuratani (1981) and Baker and Van Bavel (1987). There were two sap flow gauges installed in each of the plot stems. These gauges were changed between the stems of the disrupted and undisrupted plots on September 21st.

\subsection{Crop growth and yield measurement}

Crop growth was analyzed by getting 4 representative stems from each plot on September 25th and measuring leaf area, fresh weight and dry weight. Root development was determined using the trench profile method (Böhn, 1979) of root distribution mapping on September 27th. Crop yield was measured during the last week of December 2001.

\section{Results}

\subsection{Daily transpiration}

Figure 2 shows typical transpiration curves obtained from both the disrupted and undisrupted hardpan plots and the solar radiation curve during a fine day. The behavior of the transpiration curve almost coincides with the solar radiation curve pattern. In all daily curves, transpiration was higher in the disrupted hardpan plot than in the undisrupted one.

Figure 3 shows daily behavior of transpiration obtained from both the disrupted and undisrupted hardpan plots, and transpiration estimated by the FAO Penman-Montaith method. Figure 4 shows

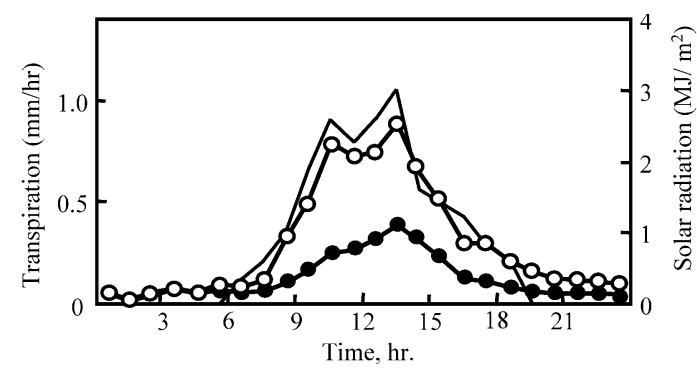

Fig. 2. Behavior of transpiration and solar radiation during a fine day of September 13.

$\bigcirc$ Disrupted, Undisrupted, - Solar radiation. 
daily precipitation during September. The total amount of precipitation during September was 888 $\mathrm{mm}, 3.5$ times as much as in a normal year. The average daily transpiration in the disrupted hardpan plot ranged from 2.5 to $9.1 \mathrm{~mm} /$ day for a monthly average of $6.3 \mathrm{~mm} /$ day. On the other hand, the transpiration in the undisrupted hardpan plot ranged from 1.2 to $4.1 \mathrm{~mm}$ /day for a monthly average of 2.9 $\mathrm{mm} /$ day.

Transpiration in the disrupted hardpan plot almost coincides with the estimated transpiration as shown in Fig. 5. The transpiration ratio of the undisrupted hardpan plot to the disrupted plot ranged from 0.29 to 0.57 for a monthly average of 0.46 , and did not

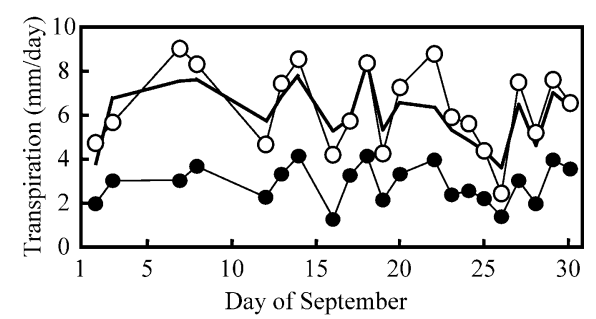

Fig. 3. Daily behavior of actual transpirations in disrupted and undisrupted hardpan plots and transpiration estimated by FAO Penman-Montaith method.

Disrupted, Undisrupted, - Estimated transpiration.

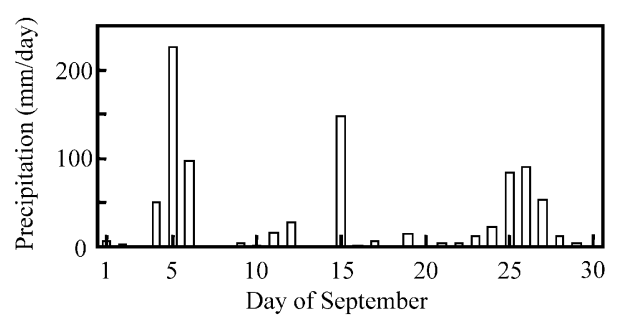

Fig. 4. Precipitation during the period of transpiration measuring. increase or decrease during the measuring period as shown in Fig. 6. However, the daily ratio decreased on the following days after the end of large precipitation events, September 7th, 16th, 27th and 28th, due to relative decrease of transpiration in the undisrupted hardpan plot.

\subsection{Crop growth and yield}

Table 1 shows the results of plant growth characteristics obtained from representative stem measuring. Leaf area index in the undisrupted hardpan plot was 0.71 of that in the disrupted plot. Plant water contents in stem and leaf blade were higher in the undisrupted hardpan plot. There were not significant differences in fresh and dry weight or leaf

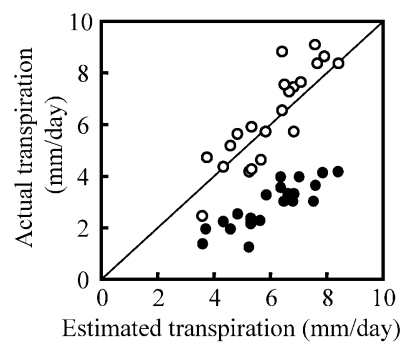

Fig. 5. Relation of estimated and actual transpirations in the disrupted and undisrupted hardpan sub-pots.

Disrupted, Undisrupted.

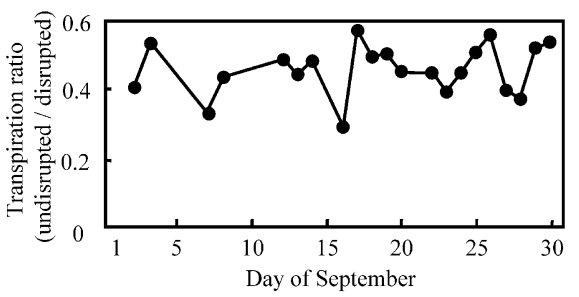

Fig. 6. Daily variation of transpiration ratio of undisrupted hardpan plot to disrupted hardpan plot.

Table 1. Characteristics of plant growth in two plots.

\begin{tabular}{|c|c|c|c|c|c|c|c|}
\hline \multirow[b]{2}{*}{ Plot } & \multirow{2}{*}{$\begin{array}{l}\text { Leaf area } \\
\text { index }\end{array}$} & \multirow{2}{*}{$\begin{array}{c}\text { Fresh } \\
\text { weight } \\
\text { (ton/ha) }\end{array}$} & \multirow{2}{*}{$\begin{array}{c}\text { Dry } \\
\text { weight } \\
\text { (ton/ha) }\end{array}$} & \multicolumn{4}{|c|}{$\%$ Water } \\
\hline & & & & $\begin{array}{c}\text { Plant } \\
\text { upper part }\end{array}$ & Stem & Leaf blade & Leaf sheath \\
\hline Disrupted & $5.21 \pm 0.93$ & $158 \pm 17$ & $46.1 \pm 5.1$ & $70.9 \pm 0.1$ & $70.5 \pm 0.0$ & $78.0 \pm 1.0$ & $67.4 \pm 2.7$ \\
\hline Undisrupted & $3.68 \pm 0.25$ & $151 \pm 13$ & $39.9 \pm 4.8$ & $73.6 \pm 0.9$ & $73.4 \pm 0.8$ & $81.5 \pm 1.3$ & $67.0 \pm 1.6$ \\
\hline
\end{tabular}

Mean \pm standard deviation. 


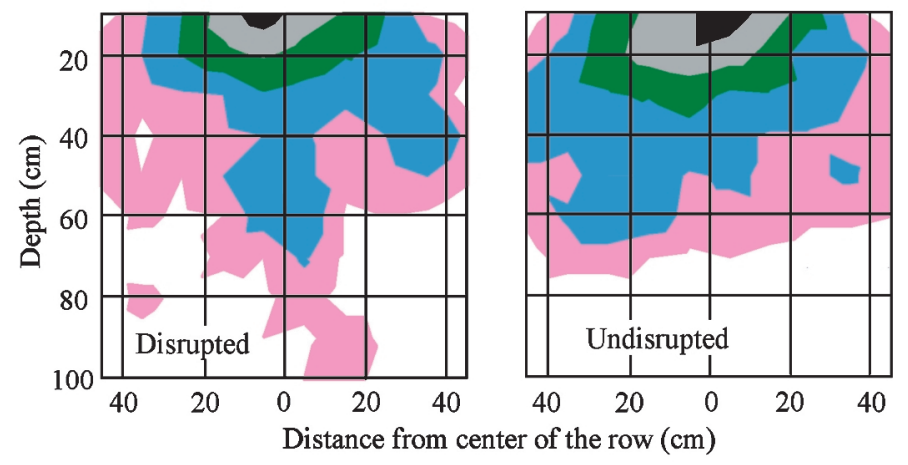

Fig. 7. Root distribution map within the soil profile of disrupted and undisrupted hardpan plots.

$\square 0-0.05 \quad \square 0.05-0.1 \quad \square 0.1-0.2$

$0.2-0.3 \square 0.3-0.4 \square 0.4-0.5 \mathrm{~cm} / \mathrm{cm}^{3}$

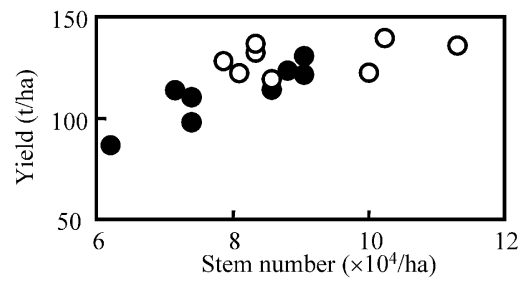

Fig. 8. Relation of stem number and yield in disrupted and undisrupted hardpan pots.

$\bigcirc$ Disrupted, Undisrupted.

sheath water content between the disrupted and the undisrupted hardpan plots.

Roots in the disrupted hardpan plot developed deeper into the sub-soil as shown in Fig. 7. However, their development in the shallow soil above the hardpan was less than that in the undisrupted hardpan plot.

As shown in Fig. 8, the number of sugarcane stems available for yield was more in the disrupted hardpan plot. This also indicated that disrupting the hardpan facilitated higher yield, relevant to the number of stems.

\section{Discussion}

\subsection{Effect of hardpan on transpiration}

The measuring period for transpiration was generally wet and therefore it can be assumed that there was enough soil water within the root zone for plant roots to absorb and plant leaves to transpire to their full potential. The transpiration estimated by the FAO Penman-Montaith method indicates the meteorological potential transpiration. This means tran- spiration in the disrupted hardpan condition was at the normal rate. Under the undisrupted hardpan condition, transpiration was below normal. In 2001, the rainy season was from May 11th to June 1st, and the precipitation during the period was $486 \mathrm{~mm}$. After the end of rainy season, the dry season continued to September 4th; precipitation during the period was $151 \mathrm{~mm}$. The fact that transpiration in the undisrupted hardpan plot did not increase during September as shown in Fig. 6 suggests that hardpan alone does not limit the effective soil water reservoir for plant roots. The fact that the ratio in Fig. 6 decreased on the days following large precipitation events suggests that plants in the undisrupted hardpan plot were more sensitive to wet injury than those in the disrupted hardpan plot. Hardpan caused some irreversible after-effects for plants during the rainy and/or dry seasons before the period of transpiration measured. Glimpses of these effects can be caught in crop growth and yield.

\subsection{Effect of hardpan on crop growth and yield}

With hardpan, crops are supposed to be subjected to two types of stress; one is plant water stress due to soil water shortage during the dry season and the other is low soil aeration stress due to poor internal drainage during the rainy season.

Leaf area index in the undisrupted hardpan plot was $71 \%$ of that of the disrupted plot. Though the small leaf area in the undisrupted hardpan plot is a factor in decreased growth and yield, the more remarkable factor is that the $71 \%$ area of leaf transpired only $46 \%$ as much as the disrupted hardpan plot level. This indicates the stomatal conductance 
in the undisrupted hardpan plot was much lower. The fresh weight in both plots was almost equal in the middle cropping stage. However, plant water content of the undisrupted hardpan plot was higher than that in the disrupted plot. Such a phenomenon is normally observed under continuous mild water stress, caused by the stomatal conductance decreasing (Ozawa, 1988).

Lower stomatal conductance decreases not only transpiration but also photosynthesis. A drop in photosynthesis decreased growth and yield in the near future as shown in Fig. 8. The transpiration in the undisrupted hardpan plot did not recover to the normal level even during the rainy month. Water absorption through the deeper developed roots in the disrupted hardpan plot probably prevented stomatal conductance from falling into an irreversible decrease. These results suggest that growth and yield in the undisrupted hardpan plot might be improved using cultural practices to prevent stomatal conductance from decreasing. For these practices, defolation to decrease transpiration more than photosynthesis (Ozawa, 1998) and foliar water spraying to increase stomatal conductance (Fukamachi et al., 2001) seems to be available.

Essentially, 2001 was a wet year, and the crops were not subjected to serious water stress, but to occasional water-log conditions. Kramer (1983) suggested that the probable effects of inadequate aeration due to poor internal drainage include reduction in yield for some crops. He further added that the amount of injury depends on the stage of plant development at which it occurs. The result that harvested stem numbers were less in the undisrupted hardpan plot as shown in Fig. 8 suggests inadequate aeration might have decreased available stems which occurred during the rainy season.

\section{Conclusion}

Based on the foregoing results, the following can be concluded:

1) Hardpan reduced sugarcane transpiration as much as half of its normal rate. The reduction did not recover even after soil water increased.

2) Yield decreased as stem numbers decreased. Hardpan decreased stem numbers and yield.

3) Transpiration per leaf area, closely approximating stomatal conductance, in the undisrupted hardpan plot was quite low. This resulted in high plant water content in the undisrupted hardpan plot. The lower stomatal conductance would decrease growth and yield due to a decrease in photosynthesis.

4) The reduction of stem numbers in the undisrupted hardpan plot was might result from poor drainage and aeration during the rainy season when available stems emerge.

\section{Acknowledgments}

The authors wish to thank Mrs. Kohji Yamato and Masakazu Hirata for their help in the plant management and the yield survey.

\section{References}

Allen, R. G., Pereira, L. S., Raes, D. and Smith, M., 1998: Crop evapotranspiration - Guidelines for computing crop water requirements. In $F A O$ irrigation and drainage paper 56. FAO, Rome, 290 pp.

Baker, J. M. and Van Bavel, C. H. M., 1987: Measurement of mass flow of water in stems of herbaceous plants. Plant Cell Environ., 10, 777-782.

Böhn, W., 1979: Root parameters and their measurement. In Methods of studying roots systems. Brühlsche Universitätsdruckerei, Lahn-Gießen, pp. 125-138.

Fukamachi, H., Tukaguchi, K., Ozawa, K., Komori, S. and Ogawa, K., 2001: Effect of foliar mist spray on root growth and photosynthesis of papaya plants. Acta Hort., 578, 373-375.

Gill, W.R. and Miller, R. D., 1956: A method for study of the influence of mechanical impedance and aeration on the growth of seedling roots. Proc. Soc. Soil Sci. Am., 20, 154-157.

Grimes, D. W., Miller, R. J. and Wiley, P. L., 1975: Cotton and corn root development in two field soils of different strength characteristics. Agron. J., 67, 519-523.

Kramer, P. J., 1983: Environment factors affecting root growth. In Water relations of plants. Academic Press, New York, pp. 164-186.

Kramer, P. J. and Boyer J. S., 1995: Roots and root system. In Water relation of plant and soils. Academic Press, San Diego, pp. 115-166.

Oussible, M., Crookstron, R. K. and Larson, W.E., 1992: Subsurface compaction reduces the root and shoot growth and grain yield of wheat. Agron. J., 84, 34-38.

Ozawa, K., 1988: Effect of coarse clods content in plowed soil on growth and yield of tomato and princemelon. Bull. Tokyo Metro. Agric. Exp. Stn., 21, 167-180 (in Japanese with English summary).

Ozawa, K., 1998: Regulation of plant water and fertilizer absorption due to root growth in sub-soil. Bull. Tohoku Natl. Agric. Exp. Stn., 93, 1-100 (in 
Japanese with English summary).

Sakuratani, T., 1981: A heat balance method for measuring water flux in the stem of intact plants. J. Agric. Meteorol. (Japan), 37, 9-17.

\section{耕盤がサトウキビの蒸散, 生育, 収量に及ぼす影響 \\ サミュエル M. コントレラス*・小沢 聖** \\ $\left(\begin{array}{c}* \text { フィリピン, 土壊・水管理局 } \\ * * \text { 国際農林水産業研究センター沖縄支所 }\end{array}\right)$}

\section{要 約}

近年，開発途上国でも機械耕䎣が広がってきた。これ でできる耕盤が根の貫入を減らして吸水を抑制するこ と, 耕盤下への水移動を抑制することはよく知られてい る。しかし, 作物の栽培生理に関する耕盤の影響の研究 は十分でない。そこで, 農業生産に及ぼす耕盤の影響を 軽減するために, 石垣島にある国際農林水産業研究セン ター（JIRCAS）沖縄支所で耕盤がサトゥキビの蒸散, 生育, 収量に及ぼす影響を解析した。

露地圃場を耕盤破砕区之耕盤無破砕区に分け，2000 年 12 月にサトウキビの 2 節茎を植え付け, 植被が発達 しきった 2001 年 9 月に蒸散を茎流センサーで測定し た。破砕区の蒸散は気象的なポテンシャルにほぼ等し かったが, 無破砕区の蒸散はその半分であった。測定期 間中の 9 月の降水量は多く, 耕盤より上に多くの根を発 達させた無破砕区では根圈土壤水分は早急に回復したに
あかかわらず，9月を通じて蒸散は増加しなかった。こ の結果は, 無破砕区での蒸散抑制の原因は土壤水分の不 足だけでないことを示す。無破砕区の葉面積に対する蒸 散の割合が極めて低かったこと, 無破砕区で体内水分が 増加したことから，この原因は不可逆的な気孔コンダク タンスの過度な低下にあるといえた。一般にこのような 気孔コンダクタンスの低下は光合成の低下を伴うため, 生育, 収量を抑制する。これを裏付けるように収量は耕 盤を破砕することにより高まった。このことは気孔コン ダクタンスの低下を防ぐ耕種的な対策が収量改善に有効 なことを示唆する。また, 収量は処理区にかかわらず茎 数の増加で多くなった。このことは, 有効茎が形成され る時期に当たる雨期の排水之通気性が耕盤破砕区で高ま り収量が改善されたことも考えられる。 キーワード: 耕盤, サトゥキビ, 収量, 蒸散, 生育 